\title{
How Companies Can Attract the Talented Vietnamese Graduates? An Experimental-Designed Investigation
}

\author{
Hideki Kakinuma $^{1}$ \\ ${ }^{1}$ Graduate School of Economics, Kyoto University, Japan \\ Correspondence: Hideki Kakinuma, Graduate School of Economics, Kyoto University, Yoshida-honmachi, \\ Sakyo-ku, Kyoto, 606-8501, Japan. E-mail: hkakinum@gmail.com
}

Received: November 28, 2014

Accepted: December 22, 2014

Online Published: January 20, 2015

doi:10.5539/ijbm.v10n2p31

URL: http://dx.doi.org/10.5539/ijbm.v10n2p31

\begin{abstract}
This study tried to investigate the selection criteria determining talented host country applicants attraction to companies operating in Vietnam. Using about 3000 experimental decision-making data retrieved from 63 undergraduates using policy-capturing methodology, the results showed that career advancement incentives such as training and development opportunity and promotional opportunity are more important rather than both monetary and environmental incentives at the stage of selecting the initial job after graduation. At the same time, the results also implied that company nationality may not be related to the decisions. The findings may encourage companies not only to reconsider their provided career advancement opportunities, but also to pronounce these improvements on potential applicants. Detailed explanations, practical implications, and future directions are provided.
\end{abstract}

Keywords: applicant attraction, career advancement incentives, policy-capturing methodology, recruitment, talent management, Vietnam

\section{Introduction}

Since 1986, after the adoption of the Đổi Mói (Renovation in English) System, Vietnamese economy has enjoyed a sustained economic growth. The average change in the growth rate of the real GDP (gross domestic product) is $5.0 \%$ in $1986 \sim 1990,8.2 \%$ in the period of $1991 \sim 1995,7.0 \%$ in $1996 \sim 2000,7.3 \%$ in $2001 \sim 2005$, and $6.3 \%$ in 2006 2010. The growth in recent years looks slowing down a little bit, however, it still can keep around 5.0\% (Note 1). To that end, Vietnam has received much attention from numerous foreign companies specifically Japanese companies in recent years (e.g., Japan Bank for International Cooperation, 2013; Japan External Trade Organization [JETRO], 2012). For example, according to JETRO (2012), the average increasing rate of Japanese companies can be estimated to $12.5 \%$ in the period of $2006 \sim 2010$. Under such exuberant conditions, scholars mentioned that almost companies in Vietnam, not only foreign-based but also local, have already been struggling for winning the war for talent (Vo, 2009; Vo \& Hannif, 2012).

As talent management, an emerging issue of human resource management research and practice, emphasized that securing talented employees is crucial to organizational success (Collings \& Mellahi, 2009; Michaels, Handfield-Jones, \& Axelrod, 2001; Scullion \& Collings, 2010). Especially in the expanding phase of economic globalization of recent decades, it can be restated that securing talented host country nationals (HCNs) and utilizing them are likely to highly important issues for companies to succeed with their own business in host countries (Perlmutter, 1969; Scullion \& Collings, 2006). In one example considered the situations above, it may be important for foreign-based companies operating in Vietnam to know the job choice preferences of Vietnamese graduates.

However, we shall remain conflicting opinions about HCNs' recruitment of foreign-based companies. One may say that foreign-based companies might be at a disadvantage compared to local companies because of lacking affinities between local employees (Caves, 2007; Newburry, Gardberg, \& Belkin, 2006), but others would suggest that foreign-based companies might be able to enjoy the strong competitiveness of better treatment which comes from their foreignness (Ahmadi \& Helms, 1997; Moy \& Lee, 2002). The employer of choice survey in Vietnam by CareerBuilder Vietnam (2013) is a good illustration of that opacity. In this survey, there are 7 foreign-based companies among top 10 employers of choice, however, Vinamilk, the largest Vietnamese multinational daily company, ranks first. That is, the effectiveness of the foreignness of the company is still open 
to question under the Vietnamese condition. In another respect, we may have to consider that which selection criteria and type of incentives are more effective to attract the talented HCNs in Vietnam.

Therefore, this study tackled to identify the impact of factors on initial job choice decision-making in the case of Vietnamese university students. Specifically, the author evaluated several selection criteria which can be categorized to monetary, career advancement, and environmental incentives. Put simply, this study might be able to suggest both the most attracted selection criterion and incentives category.

\section{Theoretical Background}

Recruitment, the first step of hiring employees, is particularly important because highly competent new hires are not only a source of competitive advantage but also critical for organizational survival (Ployhart, 2006; Taylor \& Collins, 2000; Yu \& Cable, 2014). More notably, hiring highly competent - talented - HCNs is one of the main concerns for multinational corporations because the utilization of $\mathrm{HCNs}$ as local insiders can be viewed as meaningful for both market competitiveness and local responsiveness (Evans, Pucik \& Barsoux, 2002; Scullion \& Collings, 2006). Thus, global talent management issues which discuss about managing talented employees across the globe have been occurring in recent years (e.g., Scullion \& Collings, 2010; Tarique \& Sculler, 2010).

Over the past few decades a considerable number of research have been made on the principles of recruitment and applicant attraction. As several remarkable reviewing literatures (e.g., Breaugh, 2008; Chapman, Uggreslev, Carroll, Piasentin, \& Jones, 2005; Leavens \& Chapman, 2009; Rynes \& Barber, 1990; Rynes \& Cable, 2003; Taylor \& Collins, 2000) pointed out, the majority of research focused on applicants and their reactions how applicants react to individual recruitment practices. For example, there is a large amount of studies which have investigated the relationships between applicant attractiveness or job pursuit intentions and numerous criteria and practices such as salary, promotional opportunity, job characteristics, benefit packages, corporate reputation, applicant personalities, realistic job preview, social network, recruitment sources and recruiter behavior (e.g., Collins, 2007; Duffy \& Sedlacek, 2007; Ehrhart \& Ziegert, 2005; Han \& Han, 2009; Moser, 2005; Robinson, 2003; Wanous, 1973). Although these studies suggest the importance of criteria which used in each study, a meta-analytic review by Chapman et al. (2005) confirmed that the characteristics of both the job and the organization (e.g., organization image, work environment, type of work) and perceived person-organization fit were two of the most important predictors of applicant attraction outcomes.

In view of these general understandings, let us consider the Vietnamese context. We have to admit that only few attempts have so far been made at the applicant attraction research by considering the case of Vietnam except for great works by Froese and his colleagues (e.g., Froese, Vo, \& Garrett, 2010; Kim, Froese, \& Cox, 2012). For example, Froese et al. (2010) investigated the applicability of the country of origin image framework in order to examine why job applicants are (or are not) attracted to foreign companies. As a result, Froese et al. (2010) pointed out three points; (a) The more positively Vietnamese university students perceive Japanese companies as providing career enhancing job characteristics; (b) The more positively Vietnamese university students perceive the technological development of Japan, the more attracted they will be to Japanese companies; and (c) The more Vietnamese students perceive Japanese as in-group oriented, the less they are attracted to Japanese companies. Another example, Kim et al. (2012) suggested that work-centric, money-oriented, and collectivistic Vietnamese job applicants might be more attracted to Japanese companies. Kim et al. (2012) also suggested that applicants who have a friend or a family member in a Japanese company were more attracted to Japanese companies because applicants may be regarded their closer person as a credible source of job information. Contrary to these studies using quantitative approach, Japan Institute for Labour Policy and Training [JILPT] (2010) used a qualitative approach to explore the opinion about job choice. Based on the interviews of 14 Vietnamese students studying in Hanoi, JILPT (2010) mentioned that students hope to get the job at a foreign-based or state-owned company which is operated in Vietnam because of the high salary (at foreign-based company), and high job security (at state-owned company). One interesting finding in JILPT (2010) is that Vietnamese students do not want to choose to work on overseas even though they prefer foreign-based companies. In this regard, some interviewees mentioned that Vietnamese people cannot imagine much about the staying in foreign countries for long-term to work because of lacking familiarities with foreign countries.

\section{Research Questions}

Considering the prior research, we may still be able to think what is more influential on applicant attraction of Vietnamese university students. The reasons are threefold as below. Firstly, although recruitment and applicant attraction have been objects of study for a long time, so far the study of these topics has been superficial under the Vietnamese context. Secondly, prior research which was conducted in Vietnam has the time course of investigation, and these were mainly focused on the attractiveness of not general but Japanese companies. 
Thirdly, moreover, rating individual criterion which is the way the prior research has taken may not be effective to capture the actual importance of each criterion (see, Chap.4.2 for details). Therefore, the author tackled to the exploratory research questions (RQ) below.

RQ1: Which selection criterion is the more influential for the applicant attractiveness of Vietnamese university students in general?

RQ2: Does the relationship between acquaintances who has worked at a Japanese company be effective for applicant attraction to Japanese companies?

\section{Method}

\subsection{Data and Sample}

The data used in this study were collected by the author on December 2013, at a Vietnamese prestigious university locating in Hanoi, Vietnam. Numerous students in the target faculty can converse in English well because they are attached to the international standard program taught in English, therefore, the original English version paper-based questionnaire was prepared. The author provided a printed questionnaire form for students in two business administration classes, and all already-answered questionnaires were collected. As a result, a total of 63 students answered the questionnaire validly. The respondents included 21 men (33.3\%) and 42 women (66.7\%), 39 third-year (61.9\%) and 24 fourth-year (38.1\%). Based on the observation in the university, the author regarded male-female ratio of respondents in this study as being unbiased. 35 respondents $(55.6 \%)$ have a family or a friend who has experienced working at a Japanese company.

\subsection{Measurements}

The author chose the policy-capturing methodology, which is mainly developed in the industrial and organizational psychology research, to predict the relative importance of each considerable criterion. The reason for using this methodology is that policy-capturing is able to capture how people weight, combine, or integrate available information on decision-making (Aiman-Smith, Scullen \& Barr, 2002; Karren \& Barringer, 2002; Zedeck, 1977). Although a number of studies have been made on applicant attraction by using policy-capturing (e.g., Aiman-Smith, Bauer \& Cable, 2001; Cable \& Judge, 1994; Dunn, Mount, Barrick \& Ones, 1995; Judge \& Bretz, 1992; Rynes \& Lawler, 1983), only few attempts have so far been made at in emerging countries like as Vietnam. Comparing to the direct questioning technique, policy-capturing may have several conceivable advantages; more realistic measurement, approach to deep psychological thought, and mastery of the interdependence of each information, for instance (e.g., Karren \& Barringer, 2002). Illustration from the scene of job-choice decision-making may be informative to understand such advantages. When we make a decision, we may use numerous considerable factors - e.g., salary, working atmosphere, peer relationships, working hours, commuting time to work - through unconscious filtering. There is no doubt that people need 'everything is all arranged'; accordingly, we might answer 'highly important' to the questions asking the (absolute) importance of each factor directly. However, we might be determined the relative priority of things on a deep psychological level like as 'salary is more important even if I have to work with incompatible colleagues.' Under such assumption, direct questioning might not be regarded as a good tool which can capture the real thoughts. Policy-capturing is therefore valuable in this study to measure the relative importance which will be constructed after the unconscious thoughts.

In collecting data, the author made a bundle of fictional company profiles (scenarios) that modified the level of the five selection criteria (cues). The detail of cues and its levels are as described in Table 1, consisted of three incentive categories which were chosen based on the prior research; monetary (salary), environmental (company nationality, and job characteristics), and career advancement (promotional opportunity, and training and development opportunity). By crossing these cues, the scenarios created every possible combination. With five cues, at two or three levels each, the author used $3 \times 2 \times 2 \times 2 \times 2$ design, resulting in 48 scenarios. It is ensured from this orthogonal full factorial design that we had no correlation among the criteria. This amount was within the range which Cooksey (1996) recommended, having a minimum of 40-45, a maximum of 80-90 scenarios. It can be considered that applying the full factorial design might have no problem in view of these facts, therefore, the total amount of the scenarios used in this study was forty-eight, the same as the whole amount of possible combinations.

Scenarios were provided in a state divided into four pages with random shuffling. The participants answered the attractiveness how much he or she was attracted to each scenario on 5-point scale that ranged from 1 ('strongly not preferable') to 5 ('strongly preferable'). The author ordered the participants not to return and compare to previous scenarios to keep the consistency of answers. 
Table 1. List of cues and levels

\begin{tabular}{|c|c|c|}
\hline Incentive category & Cues & Levels \\
\hline \multirow{2}{*}{ Monetary } & \multirow{2}{*}{ Salary } & Above average \\
\hline & & Average \\
\hline \multirow{5}{*}{ Environmental } & \multirow{3}{*}{ Company nationality } & Vietnamese \\
\hline & & Japanese \\
\hline & & Others (Neither Vietnamese nor Japanese) \\
\hline & \multirow{2}{*}{ Job characteristics } & Desirable for you \\
\hline & & Undesirable for you \\
\hline \multirow{4}{*}{ Career advancement } & \multirow{2}{*}{ Training and development opportunity } & Sufficient \\
\hline & & Weak \\
\hline & \multirow{2}{*}{ Promotional opportunity } & Sufficient \\
\hline & & Weak \\
\hline
\end{tabular}

The one example of scenario is as noted hereinafter; underlined words which indicate the level of cues have varied by every scenario. In the actual scenarios, underline does not exist.

The company is Vietnamese company. They will provide your undesirable job, and average salary. And also, there are weak promotional opportunities, and sufficient training and development opportunities.

\subsection{Means for Analyzing}

In this study, the evaluation of each scenario is considered as a separate decision. With 48 scenarios and 63 respondents, the author collected 3024 experimental decisions including missing cases. Put simply, from another standpoint, policy-capturing can lead us to collect the certain amount of sample from a limited number of respondents, and that amount can be tolerated to take statistical analyses. Before analyzing, the level of each cue was coded to 0 for lower and 1 for higher, except the company nationality. The company nationality was coded by two dummies; company nationality [Vietnam] ( 0 for Japanese and others, 1 for Vietnamese), and company nationality [Neither Vietnamese nor Japanese] (0 for Vietnamese and Japanese, 1 for others). As the author mentioned above, there is no correlation among these coded variables because of the orthogonal full factorial design. Finally, the author putted all the data into the single dataset to address the nomothetic questions which concerns the outcomes in general among numerous decision-makers. Thus, in the dataset, the row indicates a decision to a scenario, and the column consists of applicant attractiveness to that scenario, selection criteria (coded) of that scenario, and individual variables of the respondent.

The data were analyzed using two analyzing techniques. One is multiple regression analysis for RQ1 to determine the degree to which attractiveness of the company had been affected by five selection criteria the author chose. In these analyses, five criteria - company nationality, job characteristics, salary, promotional opportunity, and training and development opportunity-were assigned to the independent variables, and individual characteristics such as gender and university year were used as control variables. Company profiles which include independent variables (dummy variables of selection criteria) were provided by the author, and after, the respondents answered the dependent variable (applicant attractiveness) of each profile. Therefore, the author considered that it can be avoided common method variance which might be occurred when we collected both predictors and criterion variables from a single individual. The results of multiple regression analyses interpreted that the standardized partial regression coefficient of each criterion implies the relative importance of that criterion. The other is independent-samples t-test for RQ2 to check the effectiveness of the personal relationship in decisions. The author compared the mean of applicant attractiveness to Japanese companies with groups which are divided by the existence of families or friends who have worked at a Japanese company.

\section{Results}

Table 2 summarizes the results of multiple regression analyses. After omitting the missing cases, the author finally used 3009 experimental decision cases for analyzing. All of three models examined are significant at the $0.1 \%$ level, and its coefficient of determination might be considered as sufficient. As the analysis by using all samples indicates, four of the five selection criteria excepting the company nationality are significant predictors of applicant attractiveness. Out of these, training and development opportunity (.357) is the most influential selection criterion for Vietnamese university students choosing a company as their first job after graduation. Other criteria will be shown hereinafter in descending order of impact; promotional opportunity (.338), job 
characteristic (.223), and salary (.198). Job characteristic and salary have relatively low weight in the decision. The company nationality is not statistically associated with more attractiveness in the case of Vietnamese companies, but $10 \%$ significance level can be found in the case of neither Vietnamese nor Japanese.

Table 2. Multiple regression of applicant attractiveness

\begin{tabular}{|c|c|c|c|}
\hline & \multirow{2}{*}{ All } & \multicolumn{2}{|c|}{ Gender } \\
\hline & & Male & Female \\
\hline & $\beta$ & $\beta$ & $\beta$ \\
\hline Company nationality [Vietnamese] & .003 & -.014 & .010 \\
\hline Company nationality [Neither Vietnamese nor Japanese] & $-.029^{\dagger}$ & -.044 & -.022 \\
\hline Job characteristic & $.223^{* *}$ & $.233^{* *}$ & $.219^{* *}$ \\
\hline Salary & $.192^{* *}$ & $.180^{* *}$ & $.197^{* *}$ \\
\hline Promotional opportunity & $.338^{* *}$ & $.312^{* *}$ & $.351^{* *}$ \\
\hline Training and development opportunity & $.357^{* *}$ & $.335^{* *}$ & $.368^{* *}$ \\
\hline $\mathrm{R}^{2}$ & .414 & .384 & .428 \\
\hline Adjusted $\mathrm{R}^{2}$ & .400 & .368 & .414 \\
\hline $\mathrm{N}$ & 3009 & 1004 & 2005 \\
\hline
\end{tabular}

Note. Control variables were abbreviated in this table. All models are significant at the $0.1 \%$ level. $* *=\mathrm{p}<.001, *=\mathrm{p}<.010, \dagger=\mathrm{p}<.100$.

The analyses using samples which were identified through the use of gender indicated that, in both male and female samples, training and development opportunity most strongly influenced the applicants' feeling of attraction to an organization, with promotional opportunity having the next strongest influence. The third and fourth are job characteristic and salary, thus, the rank order of relative importance is the same as in all samples. The company nationality is not statistically related to attractiveness in both female and male samples.

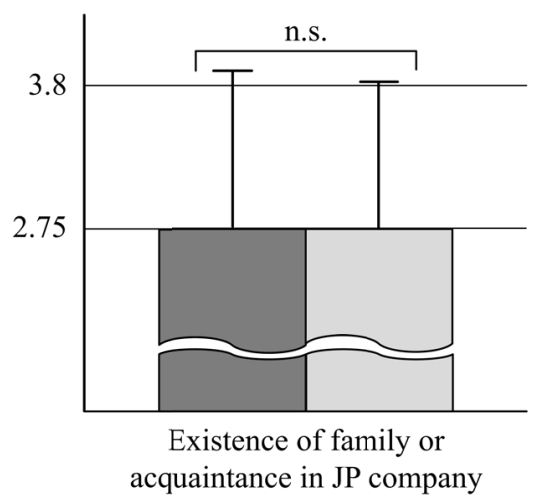

\begin{tabular}{|c|c|c|}
\cline { 2 - 3 } \multicolumn{1}{c|}{} & Mean & SD \\
\hline$\square$ Have & 2.75 & 1.19 \\
\hline Not have & 2.75 & 1.06 \\
\hline
\end{tabular}

Figure 1. T-test for applicant attractiveness to Japanese companies

The result of t-test was shown in Figure 1. About the applicant attractiveness to Japanese companies, there was not a significant difference in the scores for having a family or a friend who has worked at a Japanese company $(\mathrm{n}=560$, mean $=2.75, \mathrm{SD}=1.19)$ and not having $(\mathrm{n}=448$, mean $=2.75, \mathrm{SD}=1.06)$ conditions; $\mathrm{t}(988.870)=-.035$, $\mathrm{p}=.972$.

\section{Discussions}

The author would like to discuss the threefold. First, let us consider the reason why applicants may have put much value on career advancement opportunity. It is clear that training and development opportunity and promotional opportunity are two of the most influential selection criteria among respondents. The author thought there are two possibilities. One is related to the incomplete Vietnamese educational system. As scholars (Trung \& Swierczek, 2009; Truong \& Metzger, 2006) pointed out, there are mismatches between skills development in universities and employees' needs. It caused that educational system capable of responding appropriately to companies' demands is not fully consolidated (Nguyen \& Truong, 2007; Vo, 2009). The other possibility, which is linked with something previously mentioned, is about salary progression. The following are a few examples to 
show the importance of training and development opportunity to salary progression. Firstly, JETRO (2012) mentioned that the gap between the average salary of the staff and that of the manager is about 2.5 times. Secondly, under the Vietnamese labor law, employers should provide $7 \%$ higher salary to employees who have already attended vocational training than employees who have not (Note 2). All of this amounts to saying that employees should have to continue learning the topics related to their job to get higher ranks and salaries.

Second, contrary to the expectations, company nationality may not be important for applicants. As the author cited in the part of theoretical background, prior research mentioned that applicants may have shown the higher attractiveness to Japanese companies if he or she has an acquaintance worked at a Japanese company (Kim et al., 2012), and that applicants may prefer multinational corporations (MNCs) rather than small and medium-sized enterprises (SMEs) (Ahmadi \& Helms, 1997; Moy \& Lee, 2002). According to Vietnam, General Statistical Office of Vietnam (2013), almost 98\% of Vietnamese companies are small and medium-sized, especially about $60 \%$ companies are operating less than 10 employees. Therefore, the author thought to be re-coded Japanese and other countries' companies as MNCs, and Vietnamese companies as SMEs, in relative terms. That is, it can be said that Japanese and other countries' companies may have preferred than Vietnamese companies, under all conditions or a specific situation. However, as Table 2 and Figure 1 indicate, the results imply that applicants might not have a preference of company nationality in choosing among these companies. One possibility is to assume that applicants might not perceive the differences in job attributes between Vietnamese companies and foreign-based companies. For instance, there are several Vietnamese multinational companies (e.g., Vinamilk, FPT, Viettel, Vietnam Airlines, \& Kinh Do Corporation) who have received high attractiveness of Vietnamese applicants (see, Career Builder Vietnam, 2013). And there is another possibility that applicants might not be able to show different tendencies in choosing a company by reason of unfamiliarity with foreign countries, as JILPT (2010) mentioned.

At last, we shall discuss about the meaning of the results to companies in Vietnam not only Vietnamese but also foreign-based. The results have differences among general assumption and prior research which emphasizes the importance of salary as an important attribution (e.g., Aiman-Smith et al., 2001; Rynes, Schwab \& Heneman, 1983), therefore, almost companies in Vietnam might have to reconsider their recruitment strategies. But the author would like to be concerned here only the case of its in Japanese companies. In the personal interviews, several HR Directors in Japanese companies operating in Vietnam mentioned that their powerful resources to attract talented HCNs are (a) referring from employees, and (b) providing higher salaries (Note 3), however, the results acutely pointed out that applicant attractiveness is not highly affected by both salary and social networks. That is, it is not to be denied that Japanese companies should have to reduce this gap to attract talented university graduates better. But, following in the comments from HR Directors, we may have to take notice of the idea that applicants and employees might be shown the different preferences. Namely, graduates may be attracted by intrinsic motivation; on the other hand, employees may be attracted by extrinsic motivation. For example, the one thing can be assumed that people in the transition from university to the company might not give much weight to the higher salaries; on the contrary, people already enrolling on company might give much attention to salary.

\section{Conclusion}

In this study, the author examined the relative importance weight of selection criteria which are used to be attracted the first job after graduation from university, by considering a case of Vietnam. Using about 3000 experimental decision-making data retrieved from high-ranked Vietnamese university students who are majoring business administration, the author found that training and development opportunity most strongly influenced the applicant attraction to an organization, with promotional opportunity having the next strongest. At the same time, the results imply that Vietnamese students may not be less attracted from higher salary and specific nationality of the company. In other words, it can be said that Vietnamese graduates may prefer career advancement incentives rather than monetary and environmental incentives on the initial job choice decision-making. These findings may have both research and practical implications as below.

The academic implication of this study is not only the investigation of applicant attraction in emerging countries like as Vietnam, but also the adaptation of policy-capturing methodology to Vietnamese new graduates' job choice decision-making. As the author had mentioned before, there are only a few academic debates on applicant attraction under not only the Vietnamese context but also other emerging countries. In addition, seeing on a global basis, not many attempts have so far been made at applicant attraction research by using policy-capturing. In this study, focusing on the emerging field and adapting newly method were able to find out the renewed consideration that the relative importance of salary is lower than the existing assumption which regarded salary as an important factor for the applicants, for instance. 
There is a practical implication for foreign-based companies operating in Vietnam, which may offer some insights to succeed their recruitment activities. The results suggest that companies should have to reconsider their provided career advancement opportunities and its allocation methods. In detail, improving not only in-house training and development opportunities but also promotional opportunity, and promoting these facts to potential applicants are more important to attract the talented HCNs. In other words, there is a possibility that graduates are not attracted by higher salaries on choosing their initial job, in contradiction to the general perception. Moreover, specifically to Japanese companies in Vietnam, they may have to reconsider making a stronger employee value proposition to attract talented undergraduates by utilizing the employees' social networks.

Although this study might be able to provide several implications, the author has to admit several limitations in this study. One is about selecting a target sample. As mentioned before, this study was based on the data from 63 respondents who are belonging in the same faculty in a university. These respondents might be suitable to capture the thought of talented potential job applicants in the management major studying in Hanoi, however, there is a little possibility that they might not be a representative of talented Vietnamese university students in general. Added to this, the author should mention that the amount and divergence of respondents might not enough to be a more powerful investigation even though more than 3000 experimental decisions were used for analyzing. The other is about survey methods. By considering the procedural dilemmas of policy-capturing (see, Karren \& Barringer, 2002), the author limited the number of cues and levels to avoid information overload for the respondents. That is, there remains the possibility that other more important factors might be missed.

Despite these limitations, this study provides an example to conduct the applicant attraction survey in emerging country using policy-capturing methodology. For further consideration, the author would like to settle the three considerable directions. First, to generalize to other groups, we should conduct the same or similar survey at other faculties, universities, and cities. Added to these, comparative study among emerging countries in Asian region may be interesting, to investigate the most suitable country to attract talented university students to Japanese companies as an initial working place. Second, to complement the lack of reflecting considerable job attitudes, we should take some interviews for further understanding of the Vietnamese graduates' job choice decisions. Moreover, we also have to struggle with the mastery of the procedural dilemmas for collecting the data. For example, it may make more sense to take a fractional factorial design on policy-capturing which has a number of similarities to the conjoint analysis (see, Aiman-Smith et al., 2002).

\section{Acknowledgments}

This study was supported in part by grants from Kyoto University Asian Studies Unit. An earlier version was presented by the author at the Paris Colloquium on Human Resource Management in Asia: Distinctiveness of Asian Human Resource Management?, which was held in Paris, France, 17-18, September 2014; with Xiang Yin (Graduate School of Economics, Kyoto University, Japan), Nham Phong Tuan (VNU University of Economics and Business, Vietnam) and Naoki Wakabayashi (Graduate School of Management, Kyoto University, Japan). The author totally reconstructed that presentation, therefore, only the author takes full responsibility for the wording and content of this article.

\section{References}

Ahmadi, M., \& Helms, M. M. (1997). Small firms, big opportunities: The potential of careers for business graduates in SMEs. Education + Training, 39(2), 52-57. http://dx.doi.org/10.1108/00400919710164134

Aiman-Smith, L., Bauer, T., \& Cable, D. (2001). Are you attracted? Do you intend to pursue? A recruiting policy-capturing study. Journal of Business and Psychology, 16(2), 219-237. http://dx.doi.org/10.1023/A:1011157116322

Aiman-Smith, L., Scullen, S. E., \& Barr, S. H. (2002). Conducting studies of decision making in organizational contexts: A tutorial for policy-capturing and other regression-based techniques. Organizational Research Methods, 5(4), 388-414. http://dx.doi.org/10.1177/109442802237117

Breaugh, J. A. (2008). Employee recruitment: Current knowledge and important areas for future research. Human Resource Management Review, 18(3), 103-118. http://dx.doi.org/10.1016/j.hrmr.2008.07.003

Cable, D. M., \& Judge, T. (1994). Pay preferences and job search decisions: A person-organization fit perspective. Personnel Psychology, 47(2), 317-348. http://dx.doi.org/10.1111/j.1744-6570.1994.tb01727.x

Career Builder Vietnam. (2013). Employers of Choice Survey 2013. PDF version retrieved from http://careerbuilder.vn/ 
Caves, R. (2007). Multinational Enterprise and Economic Analysis (3rd ed.). Cambridge University Press.

Chapman, D. S., Uggerslev, K. L., Carroll, S. A., Piasentin, K. A., \& Jones, D. A. (2005). Applicant attraction to organizations and job choice: A meta-analytic review of the correlates of recruiting outcomes. Journal of Applied Psychology, 90(5), 928-944. http://dx.doi.org/10.1037/0021-9010.90.5.928

Collings, D. G., \& Mellahi, K. (2009). Strategic talent management: A review and research agenda. Human Resource Management Review, 19(4), 304-313. http://dx.doi.org/10.1016/j.hrmr.2009.04.001

Collins, C. J. (2007). The interactive effects of recruitment practices and product awareness on job seekers' employer knowledge and application behaviors. Journal of Applied Psychology, 92(1), 180-190. http://dx.doi.org/10.1037/0021-9010.92.1.180

Cooksey, R. W. (1996). Judgment Analysis: Theory, Methods, and Applications. Academic Press.

Duffy, R. D., \& Sedlacek, E. (2007). The work value of first-year college students: Exploring group differences. Career Development Quarterly, 55(4), 359-364. http://dx.doi.org/10.1002/j.2161-0045.2007.tb00090.x

Dunn, W. S., Mount, M. K., Barrick, M. R., \& Ones, D. S. (1995). Relative importance of personality and general mental ability in managers' judgments of applicant qualifications. Journal of Applied Psychology, 80(4), 500-509. http://dx.doi.org/10.1037/0021-9010.80.4.500

Ehrhart, K. H., \& Ziegert, J. C. (2005). Why are individuals attracted to organizations? Journal of Management, 31(6), 901-919. http://dx.doi.org/10.1177/0149206305279759

Evans, P. A. L., Pucik, V., \& Barsoux, J. L. (2002). The Global Challenge: International Human Resource Management. McGraw-Hill.

Froese, F. J., Vo, A., \& Garrett, T. (2010). Organizational attractiveness of foreign-based companies: A country of origin perspective. International Journal of Selection and Assessment, 18(3), 271-281. http://dx.doi.org/10.1111/j.1468-2389.2010.00510.x

Han, J., \& Han, J. (2009). Network-based recruiting and applicant attraction in China: Insights from both organizational and individual perspectives. International Journal of Human Resource Management, 20(11), 2228-2249. http://dx.doi.org/10.1080/09585190903239633

Japan Bank for International Cooperation. (2013). FY 2013 (25th) Survey Report on Overseas Business Operations by Japanese Manufacturing Companies. Retrieved from https://www.jbic.go.jp/en/information/press/press-2013/1129-15929

Japan External Trade Organization [JETRO]. (2012). Fact Sheet of Vietnamese Economy 2012. Retrieved from http://www.jetro.go.jp/

Japan Institute for Labour Policy and Training [JILPT]. (2010). A survey report on the job awareness and practical use of highly skilled foreign personnel in Asian countries. JILPT Research Material Series, 80. (In Japanese)

Judge, T. A., \& Bretz, R. D. (1992). Effects of work values on job choice decisions. Journal of Applied Psychology, 77, 261-271. http://dx.doi.org/10.1037/0021-9010.77.3.261

Karren, R. J., \& Barringer, M. (2002). A review and analysis of the policy-capturing in organizational research: Guidelines for research and practice. Organizational Research Methods, 5(4), 337-362. http://dx.doi.org/10.1177/109442802237115

Kim, S., Froese, F. J., \& Cox, A. (2012). Applicant attraction to foreign companies: The case of Japanese companies in Vietnam. Asia Pacific Journal of Human Resources, 50(4), 439-458. http://dx.doi.org/10.1111/j.1744-7941.2012.00038.x

Lievens, F., \& Chapman, D. S. (2009). Recruitment and selection. In A. Wilkinson, T. Redman, S. Snell, \& N. Bacon (Eds.), The SAGE Handbook of Human Resource Management (pp. 133-154) Sage Publications.

Michaels, E. H., Handfield-Jones, H., \& Axelrod, B. (2001). The War for Talent. Harvard Business School Press.

Moser, K. (2005). Recruitment sources and post-hire outcomes: The mediating role of unmet expectations. International Journal of Selection and Assessment, 13(3), 188-197. http://dx.doi.org/10.1111/j.1468-2389.2005.00314.x

Moy, J. W., \& Lee, S. M. (2002). The career choice of business graduates: SMEs or MNCs? Career Development International, 7(6), 339-347. http://dx.doi.org/10.1108/13620430210444367 
Newburry, W., Gardberg, N., \& Belkin, L. (2006). Organizational attractiveness is in the eye of the beholder: The interaction of demographic characteristics with foreignness. Journal of International Business Studies, 37(5), 666-686. http://dx.doi.org/10.1057/palgrave.jibs.8400218

Nguyen, N. T., \& Truong, Q. (2007). International briefing 18: Training and development in Vietnam. International Journal of Training and Development, 11(2), 139-149. http://dx.doi.org/10.1111/j.1468-2419.2007.00275.x

Perlmutter, H. V. (1969). The tortuous evolution of multinational enterprises. Columbia Journal of World Business, 1, 9-18.

Ployhart, R. E. (2006). Staffing in the 21st century: New challenges and strategic opportunities. Journal of Management, 32(6), 868-897. http://dx.doi.org/10.1177/0149206306293625

Robinson, P. A. (2003). The embeddedness of Japanese HRM practices: The case of recruiting. Human Resource Management Review, 13(3), 439-455. http://dx.doi.org/10.1016/S1053-4822(03)00045-7

Rynes, S. L., \& Barber, A. E. (1990). Applicant attraction strategies: An organizational perspective. Academy of Management Review, 15(2), 286-310. http://dx.doi.org/10.5465/AMR.1990.4308158

Rynes, S. L., \& Cable, D. M. (2003). Recruitment research in the twenty-first century. In W. Borman, D. Ilgen, and R. Klimoski (Eds.), Handbook of Psychology: Industrial and Organizational Psychology (Vol. 12. pp. 55-57). John Wiley. http://dx.doi.org/10.1002/0471264385.wei1204

Rynes, S. L., \& Lawler, J. (1983). A policy-capturing investigation of the role of expectancies in decisions to pursue job alternatives. Journal of Applied Psychology, 68, 620-631. http://dx.doi.org/10.1037/0021-9010.68.4.620

Rynes, S. L., Schwab, D. P., \& Heneman, H. G. (1983). The role of pay and market pay variability in job application decisions. Organizational Behavior and Human Performance, 31, 353-364. http://dx.doi.org/10.1016/0030-5073(83)90130-7

Scullion, H., \& Collings, D. G. (2006). Global Staffing. Routledge.

Scullion, H., \& Collings, D. G. (2010). Global Talent Management. Routledge.

Tarique, I., \& Schuler, R. (2010). Global talent management: Literature review, integrative framework, and suggestions for further research. Journal of World Business, 45(2), 122-133. http://dx.doi.org/10.1016/j.jwb.2009.09.019

Taylor, M. S., \& Collins, C. J. (2000). Organizational recruitment: Enhancing the intersection of research and practice. In C. L. Cooper, and E. A. Locke (Eds.), Industrial and Organizational Psychology: Linking Theory with Practice (pp. 304-334). Blackwell Publishing.

Trung, T. Q., \& Swierczek, F. W. (2009). Skills development in higher education in Vietnam. Asia Pacific Business Review, 15(4), 565-586. http://dx.doi.org/10.1080/13602380802364175

Truong, Q. D., \& Metzger, C. (2006). Quality of business graduates in Vietnamese institutions: Multiple perspectives. Journal of Management Development, 26(7), 629-643. http://dx.doi.org/10.1108/02621710710761261

Vietnam, General Statistical Office of Vietnam. (2013). Vietnam Statistical Yearbook 2012. Retrieved from http://www.gso.gov.vn/

Vo, A. N. (2009). The Transformation of Human Resource Management and Industrial Relations in Vietnam. Chandos Publishing.

Vo, A. N., \& Hannif, Z. (2012). The transfer of training and development practices in Japanese subsidiaries in Vietnam. Asia Pacific Journal of Human Resources, 50(1), 75-91. http://dx.doi.org/10.1111/j.1744-7941.2011.00007.x

Wanous, J. P. (1973). Effects of a realistic job preview on job acceptance, job attitudes, and job survival. Journal of Applied Psychology, 58(3), 327-332. http://dx.doi.org/10.1037/h0036305

Yu, K. Y. T., \& Cable, D. M. (2014). The Oxford Handbook of Recruitment. Oxford University Press.

Zedeck, S. (1977). An information processing model and approach to the study of motivation. Organizational Behavior and Human Performance, 18, 47-77. http://dx.doi.org/10.1016/0030-5073(77)90018-6 


\section{Notes}

Note 1. Statistical economic values mentioned in this paragraph calculated by the author, the data retrieved from The World Economic Outlook Database October 2013, http://www.imf.org/external/index.htm

Note 2. The Labor Code of the Socialist Republic of Vietnam (No.49/2013/ND-CP), English version retrieved from http://www.ilo.org/dyn/natlex/

Note 3. Based on personal interviews with HR Directors of Japanese companies in Vietnam, December 2013.

\section{Copyrights}

Copyright for this article is retained by the author(s), with first publication rights granted to the journal.

This is an open-access article distributed under the terms and conditions of the Creative Commons Attribution license (http://creativecommons.org/licenses/by/3.0/). 